\title{
Synthesis, Spectral Characterization and Biological Studies of Lanthanum(III) Complexes with 3-Substituted-4-Amino-5-Mercapo-1,4-Triazoles Schiff Bases
}

\author{
Mallikarjun S. Yadawe ${ }^{1, *}$, Shrishila N. Unki ${ }^{1}$, Sangamesh A. Patil ${ }^{2, \star *}$ \\ ${ }^{1}$ S.B. Arts and K.C.P. Science College, Bijapur, Karnataka, India \\ ${ }^{2}$ Department of Chemistry, Karnataka University, Dharwad - 580003, Karnataka, India \\ *,**E-mail address: mallikarjun_yadawe@yahoo.com , patil1956@rediffmail.com
}

\begin{abstract}
Some lanthanum(III) complexes have been synthesized by reacting lanthanum(III) metal salt with Schiff bases derived from 3-substituted-4-amino-5-mercapto-1,2,4-triazole and glyoxal/ biacetyl/ benzyl. All these complexes are not soluble in common organic solvents. However sparingly soluble in DMF and DMSO. The chemical analysis of the complexes confirmed to the stoichiometry of the type $\mathrm{La}(\mathrm{III}) \mathrm{LNO}_{3} \cdot \mathrm{H}_{2} \mathrm{O}$. $\mathrm{La}(\mathrm{III}) \mathrm{LCl} \cdot \mathrm{H}_{2} \mathrm{O}$ and $\mathrm{La}(\mathrm{III}) \mathrm{LNCS} \cdot \mathrm{H}_{2} \mathrm{O}$ respectively. The chelation of the complexes has been proposed in the light of analytical, spectral studies. The measured molar conductance values indicate that, the complexes are non-electrolytes. The Schiff bases and their complexes have been screened for their antibacterial and antifungal activities. The results of these studies show the metal complexes to be more antibacterial and antifungal as compared to the uncomplexed coumarins.
\end{abstract}

Keywords: lanthanum(III) complexes; Schiff; antibacterial; antifungal

\section{INTRODUCTION}

Several complexes of various transition metals with 3-substituted-4-amino-5-mercapto1,2,4-triazole ligands have been reported from our laboratory ${ }^{1-6}$. Metal complexes of 1,2,4triazole derivatives have been investigated in previous reports ${ }^{7,8}$. Substituted triazoles are well known as bactericides, ${ }^{9}$ pesticides ${ }^{10}$, insecticides ${ }^{11}$ and potential fungicides ${ }^{12}$. Recently a number of attempts have been made to obtain $\mathrm{Zn}, \mathrm{Cd}$ and $\mathrm{Hg}$ complexes with the Schiff base derived from 3-substituted-4-amino-5-mercapto-1,2,4-triazole ${ }^{13}$. Mishra et al, have studied the $\mathrm{Ru}(\mathrm{II})$ complexes of 3-substituted-4-amino-5-mercapto-1,2,4-triazole ${ }^{14}$.

In our pursuit of new ligands for metal complexes, we have synthesized a new series of Schiff bases derived by the condensation of 3-substituted-4-amino-5-mercapto-1,2,4-triazole and gyyoxal/biacetyl/benzyl. These ligands have donor sites with the ONNO sequence and varied coordination abilities. The nature of ligands has attributed our attention and aroused our interest in elucidating the structures of $\mathrm{La}(\mathrm{III})$ complexes with the Schiff bases as there is 
scant information on these complexes of the ligands. Hence, in this paper we have report the synthesis, spectral and biological activities of $\mathrm{La}$ (III) complexes with the following synthesized ligands (Fig. 1).

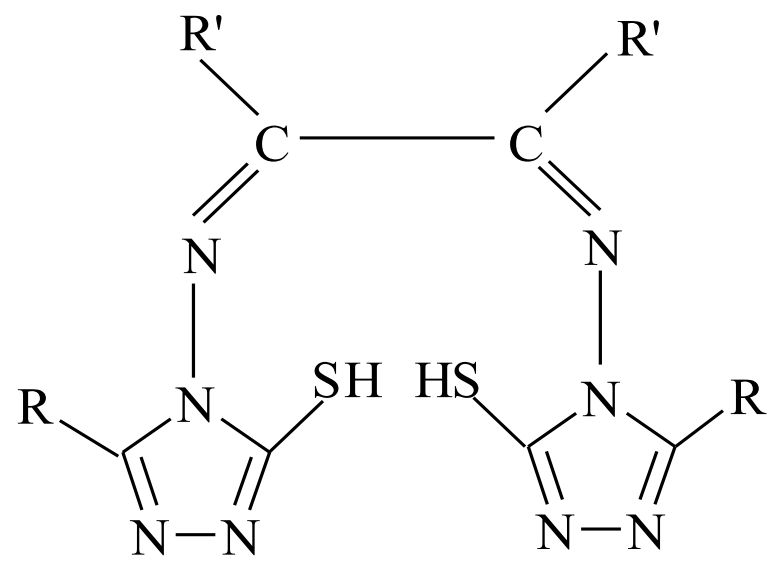

Fig. 1. Structure of Schiff bases.

\begin{tabular}{ccc}
\hline Schiff bases No. & $\mathbf{R}^{\prime}$ & $\mathbf{R}$ \\
\hline I & $\mathrm{H}$ & $\mathrm{H}$ \\
II & $\mathrm{H}$ & $\mathrm{CH}_{3}$ \\
III & $\mathrm{H}$ & $\mathrm{C}_{2} \mathrm{H}_{5}$ \\
IV & $\mathrm{H}$ & $\mathrm{C}_{3} \mathrm{H}_{7}$ \\
V & $\mathrm{CH}_{3}$ & $\mathrm{H}$ \\
VI & $\mathrm{CH}_{3}$ & $\mathrm{CH}_{3}$ \\
VII & $\mathrm{CH}_{3}$ & $\mathrm{C}_{2} \mathrm{H}_{5}$ \\
VIII & $\mathrm{CH}_{3}$ & $\mathrm{C}_{3} \mathrm{H}_{7}$ \\
IX & $\mathrm{C}_{6} \mathrm{H}_{5}$ & $\mathrm{H}$ \\
X & $\mathrm{C}_{6} \mathrm{H}_{5}$ & $\mathrm{CH}_{3}$ \\
XI & $\mathrm{C}_{6} \mathrm{H}_{5}$ & $\mathrm{C}_{2} \mathrm{H}_{5}$ \\
XII & $\mathrm{C}_{6} \mathrm{H}_{5}$ & $\mathrm{C}_{3} \mathrm{H}_{7}$ \\
\hline
\end{tabular}

\section{EXPERIMENTAL}

All chemicals used were of reagent grade. Substituted salicylaldehydes were prepared as described in the literature ${ }^{15}$.

\section{1. Synthesis of Schiff bases [I-XII]}

The Schiff bases have been synthesized by condensation of 3-substituted-4-amino-5mercapto-1,2,4-triazole and glyoxal/biacetyl/benzyl in 2:1 molar proportions in EtOH for 4-5 
$\mathrm{h}$ with an addition of 3-4 drops of concentrated hydrochloric acid. The precipitate formed were filtered, washed with cold $\mathrm{EtOH}$ and recrystallized from hot EtOH.

\section{2. Synthesis of Lanthanum(III) Complexes}

A solution of lanthanum(III) nitrate / lanthanum(III) chloride / lanthanum(III) thiocyanate $(0.01 \mathrm{~mol})$ was treated with $(0.01 \mathrm{~mol})$ Schiff bases in super dry alcohol. The reaction mixture was refluxed for about 2-3 hrs. After cooling $\mathrm{pH}$ of the reaction mixture was adjusted to about $\mathrm{ca} 7$ by adding dilute ammonia with constant stirring. The light yellow precipitate of complex was obtained. Then the precipitated complex was filtered, washed thoroughly with dry ethanol and ether and finally dried over fused calcium chloride in vacuum.

\section{3. Analysis and Physical Measurements}

The lanthanum in the complex was determined by volumetric method using EDTA solution ${ }^{18}$. The nitrogen was determined by Dumas method. The results of chemical analysis and molar conductance values are listed in Table 1.

The IR spectra of the ligands and their lanthanum(III) complexes were recorded on a HITACHI-270 IR spectrophotometer in the $4000-250 \mathrm{~cm}^{-1}$ region in $\mathrm{KBr}$ disc. The electronic spectra of the complexes were recorded on a VARIAN CARY 50-BIO UVspectrophotometer in the region of 200-1100 $\mathrm{nm}$.

Table 1. Analytical and Molar Conductance Data of Lanthanum(III) complexes of 3-substituted-4amino-5-mercapto-1,2,4-triazole and glyoxal/biacetyl/benzyl.

\begin{tabular}{|c|c|c|c|c|c|c|c|}
\hline 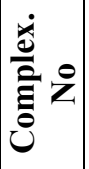 & Empirical formula & $\begin{array}{l}\text { M \% } \\
\text { Cald. } \\
\text { Obtd. }\end{array}$ & $\begin{array}{l}\text { N \% } \\
\text { Cald. } \\
\text { Obtd. }\end{array}$ & & $\begin{array}{l}\% \\
\text { Id. } \\
\text { td. }\end{array}$ & $\begin{array}{l}\text { Cl \% } \\
\text { Cald. } \\
\text { Obtd. }\end{array}$ & $\begin{array}{c}\text { Molar } \\
\text { conductanc } \\
\text { e Ohm } \\
\text { cm }^{-1} \text { mole }^{-1}\end{array}$ \\
\hline 1 & $\left(\mathrm{C}_{6} \mathrm{H}_{4} \mathrm{~N}_{8} \mathrm{~S}_{2}\right) \mathrm{LaNO}_{3} \cdot \mathrm{H}_{2} \mathrm{O}$ & $29.49 \quad 30.68$ & 26.7527 .85 & 13.59 & 14.10 & - & 13.53 \\
\hline 2 & $\left(\mathrm{C}_{8} \mathrm{H}_{8} \mathrm{~N}_{8} \mathrm{~S}_{2}\right) \mathrm{LaNO}_{3} \cdot \mathrm{H}_{2} \mathrm{O}$ & $27.84 \quad 27.90$ & $25.28 \quad 25.18$ & 12.82 & 13.34 & & 12.59 \\
\hline 3 & $\left(\mathrm{C}_{10} \mathrm{H}_{12} \mathrm{~N}_{8} \mathrm{~S}_{2}\right) \mathrm{LaNO}_{3} \cdot \mathrm{H}_{2} \mathrm{O}$ & 26.3626 .31 & $23.91 \quad 24.09$ & 12.14 & 12.10 & - & 15.42 \\
\hline 4 & $\left(\mathrm{C}_{12} \mathrm{H}_{16} \mathrm{~N}_{8} \mathrm{~S}_{2}\right) \mathrm{LaNO}_{3} \cdot \mathrm{H}_{2} \mathrm{O}$ & $25.03 \quad 25.09$ & 22.7122 .81 & 11.53 & 11.94 & - & 16.92 \\
\hline 5 & $\left(\mathrm{C}_{8} \mathrm{H}_{8} \mathrm{~N}_{8} \mathrm{~S}_{2}\right) \mathrm{LaNO}_{3} \cdot \mathrm{H}_{2} \mathrm{O}$ & $27.84 \quad 27.90$ & $25.25 \quad 25.32$ & 12.82 & 1232 & - & 17.94 \\
\hline 6 & $\left(\mathrm{C}_{10} \mathrm{H}_{12} \mathrm{~N}_{8} \mathrm{~S}_{2}\right) \mathrm{LaNO}_{3} \cdot \mathrm{H}_{2} \mathrm{O}$ & 26.3626 .39 & $23.91 \quad 23.85$ & 12.14 & 12.58 & - & 20.84 \\
\hline 7 & $\left(\mathrm{C}_{12} \mathrm{H}_{16} \mathrm{~N}_{8} \mathrm{~S}_{2}\right) \mathrm{LaNO}_{3} \cdot \mathrm{H}_{2} \mathrm{O}$ & $25.03 \quad 25.09$ & 22.7022 .75 & 11.53 & 11.63 & - & 26.03 \\
\hline 8 & $\left(\mathrm{C}_{14} \mathrm{H}_{20} \mathrm{~N}_{8} \mathrm{~S}_{2}\right) \mathrm{LaNO}_{3} \cdot \mathrm{H}_{2} \mathrm{O}$ & $23.82 \quad 23.60$ & 21.6121 .65 & 10.97 & 10.33 & - & 24.84 \\
\hline 9 & $\left(\mathrm{C}_{18} \mathrm{H}_{12} \mathrm{~N}_{8} \mathrm{~S}_{2}\right) \mathrm{LaNO}_{3} \cdot \mathrm{H}_{2} \mathrm{O}$ & $22.29 \quad 22.18$ & 20.2320 .31 & 10.28 & 10.59 & - & 28.65 \\
\hline 10 & $\left(\mathrm{C}_{20} \mathrm{H}_{16} \mathrm{~N}_{8} \mathrm{~S}_{2}\right) \mathrm{LaNO}_{3} \cdot \mathrm{H}_{2} \mathrm{O}$ & $21.33 \quad 21.96$ & $19.35 \quad 19.38$ & 9.83 & 10.12 & - & 14.78 \\
\hline 11 & $\left(\mathrm{C}_{22} \mathrm{H}_{20} \mathrm{~N}_{8} \mathrm{~S}_{2}\right) \mathrm{LaNO}_{3} \cdot \mathrm{H}_{2} \mathrm{O}$ & $20.45 \quad 20.40$ & 18.5618 .61 & 9.42 & 9.70 & - & 18.26 \\
\hline 12 & $\left(\mathrm{C}_{24} \mathrm{H}_{24} \mathrm{~N}_{8} \mathrm{~S}_{2}\right) \mathrm{LaNO}_{3} \cdot \mathrm{H}_{2} \mathrm{O}$ & 19.6419 .63 & $16.82 \quad 15.82$ & 9.05 & 9.10 & - & 19.63 \\
\hline
\end{tabular}




\begin{tabular}{|c|c|c|c|c|c|c|c|c|c|}
\hline 13 & $\left(\mathrm{C}_{6} \mathrm{H}_{4} \mathrm{~N}_{8} \mathrm{~S}_{2}\right) \mathrm{LaCl} \cdot \mathrm{H}_{2} \mathrm{O}$ & 31.25 & 31.27 & 25.20 & 25.22 & 14.40 & 14.38 & $\begin{array}{l}7.98 \\
7.95\end{array}$ & 16.30 \\
\hline 14 & $\left(\mathrm{C}_{8} \mathrm{H}_{8} \mathrm{~N}_{8} \mathrm{~S}_{2}\right) \mathrm{LaCl} \cdot \mathrm{H}_{2} \mathrm{O}$ & 29.40 & 29.42 & 23.70 & 23.68 & 13.54 & 13.52 & $\begin{array}{l}7.51 \\
7.52\end{array}$ & 12.09 \\
\hline 15 & $\left(\mathrm{C}_{10} \mathrm{H}_{12} \mathrm{~N}_{8} \mathrm{~S}_{2}\right) \mathrm{LaCl} \cdot \mathrm{H}_{2} \mathrm{O}$ & 27.75 & 27.78 & 22.38 & 22.35 & 12.78 & 12.75 & $\begin{array}{l}7.09 \\
7.05\end{array}$ & 16.06 \\
\hline 16 & $\left(\mathrm{C}_{12} \mathrm{H}_{16} \mathrm{~N}_{8} \mathrm{~S}_{2}\right) \mathrm{LaCl} \cdot \mathrm{H}_{2} \mathrm{O}$ & 26.28 & 26.26 & 21.19 & 21.20 & 12.11 & 12.12 & $\begin{array}{l}6.71 \\
6.72\end{array}$ & 13.44 \\
\hline 17 & $\left(\mathrm{C}_{8} \mathrm{H}_{8} \mathrm{~N}_{8} \mathrm{~S}_{2}\right) \mathrm{LaCl} \cdot \mathrm{H}_{2} \mathrm{O}$ & 29.40 & 29.42 & 23.70 & 23.72 & 13.54 & 13.53 & $\begin{array}{l}7.51 \\
7.53\end{array}$ & 12.19 \\
\hline 18 & $\left(\mathrm{C}_{10} \mathrm{H}_{12} \mathrm{~N}_{8} \mathrm{~S}_{2}\right) \mathrm{LaCl} \cdot \mathrm{H}_{2} \mathrm{O}$ & 27.75 & 27.79 & 22.38 & 22.36 & 12.78 & 12.80 & $\begin{array}{l}7.09 \\
7.05\end{array}$ & 10.61 \\
\hline 19 & $\left(\mathrm{C}_{12} \mathrm{H}_{16} \mathrm{~N}_{8} \mathrm{~S}_{2}\right) \mathrm{LaCl} \cdot \mathrm{H}_{2} \mathrm{O}$ & 26.28 & 26.30 & 21.19 & 21.18 & 12.11 & 12.13 & $\begin{array}{l}6.71 \\
6.75\end{array}$ & 18.10 \\
\hline 20 & $\left(\mathrm{C}_{14} \mathrm{H}_{20} \mathrm{~N}_{8} \mathrm{~S}_{2}\right) \mathrm{LaCl} \cdot \mathrm{H}_{2} \mathrm{O}$ & 24.96 & 24.98 & 20.12 & 20.14 & 11.50 & 11.48 & $\begin{array}{l}6.38 \\
6.40\end{array}$ & 12.83 \\
\hline 21 & $\left(\mathrm{C}_{18} \mathrm{H}_{12} \mathrm{~N}_{8} \mathrm{~S}_{2}\right) \mathrm{LaCl} \cdot \mathrm{H}_{2} \mathrm{O}$ & 23.28 & 23.25 & 18.77 & 18.75 & 10.73 & 10.75 & $\begin{array}{l}5.95 \\
5.96\end{array}$ & 17.94 \\
\hline 22 & $\left(\mathrm{C}_{20} \mathrm{H}_{16} \mathrm{~N}_{8} \mathrm{~S}_{2}\right) \mathrm{LaCl} \cdot \mathrm{H}_{2} \mathrm{O}$ & 22.24 & 22.20 & 17.93 & 17.90 & 10.24 & 10.20 & $\begin{array}{l}5.68 \\
5.70\end{array}$ & 22.90 \\
\hline 23 & $\left(\mathrm{C}_{22} \mathrm{H}_{20} \mathrm{~N}_{8} \mathrm{~S}_{2}\right) \mathrm{LaCl} \cdot \mathrm{H}_{2} \mathrm{O}$ & 21.29 & 21.30 & 17.16 & 17.15 & 9.80 & 9.82 & $\begin{array}{l}5.44 \\
5.42\end{array}$ & 16.13 \\
\hline 24 & $\left(\mathrm{C}_{24} \mathrm{H}_{24} \mathrm{~N}_{8} \mathrm{~S}_{2}\right) \mathrm{LaCl} \cdot \mathrm{H}_{2} \mathrm{O}$ & 20.41 & 20.40 & 16.46 & 16.45 & 9.40 & 9.42 & $\begin{array}{l}5.21 \\
5.19 \\
\end{array}$ & 19.14 \\
\hline 25 & $\left(\mathrm{C}_{6} \mathrm{H}_{4} \mathrm{~N}_{8} \mathrm{~S}_{2}\right) \mathrm{LaNCS} \cdot \mathrm{H}_{2} \mathrm{O}$ & 29.74 & 29.75 & 26.98 & 26.95 & 20.56 & 20.58 & - & 12.34 \\
\hline 26 & $\left(\mathrm{C}_{8} \mathrm{H}_{8} \mathrm{~N}_{8} \mathrm{~S}_{2}\right) \mathrm{LaNCS} \cdot \mathrm{H}_{2} \mathrm{O}$ & 28.06 & 28.09 & 25.45 & 25.47 & 19.39 & 19.37 & - & 19.35 \\
\hline 27 & $\left(\mathrm{C}_{10} \mathrm{H}_{12} \mathrm{~N}_{8} \mathrm{~S}_{2}\right) \mathrm{LaNCS} \cdot \mathrm{H}_{2} \mathrm{O}$ & 26.56 & 26.54 & 24.09 & 24.05 & 18.35 & 18.32 & - & 16.18 \\
\hline 28 & $\left(\mathrm{C}_{12} \mathrm{H}_{16} \mathrm{~N}_{8} \mathrm{~S}_{2}\right) \mathrm{LaNCS} \cdot \mathrm{H}_{2} \mathrm{O}$ & 25.21 & 25.22 & 22.87 & 22.88 & 17.42 & 17.44 & - & 14.93 \\
\hline 29 & $\left(\mathrm{C}_{8} \mathrm{H}_{8} \mathrm{~N}_{8} \mathrm{~S}_{2}\right) \mathrm{LaNCS} \cdot \mathrm{H}_{2} \mathrm{O}$ & 28.06 & 28.05 & 25.45 & 25.49 & 19.39 & 19.32 & - & 16.34 \\
\hline 30 & $\left(\mathrm{C}_{10} \mathrm{H}_{12} \mathrm{~N}_{8} \mathrm{~S}_{2}\right) \mathrm{LaNCS} \cdot \mathrm{H}_{2} \mathrm{O}$ & 26.56 & 26.55 & 24.09 & 24.10 & 18.35 & 18.30 & - & 20.18 \\
\hline 31 & $\left(\mathrm{C}_{12} \mathrm{H}_{16} \mathrm{~N}_{8} \mathrm{~S}_{2}\right) \mathrm{LaNCS} \cdot \mathrm{H}_{2} \mathrm{O}$ & 25.21 & 25.33 & 22.80 & 22.83 & 17.42 & 17.45 & - & 22.13 \\
\hline 32 & $\left(\mathrm{C}_{14} \mathrm{H}_{20} \mathrm{~N}_{8} \mathrm{~S}_{2}\right) \mathrm{LaNCS} \cdot \mathrm{H}_{2} \mathrm{O}$ & 23.99 & 23.86 & 21.76 & 21.80 & 16.58 & 16.55 & - & 17.14 \\
\hline 33 & $\left(\mathrm{C}_{18} \mathrm{H}_{12} \mathrm{~N}_{8} \mathrm{~S}_{2}\right) \mathrm{LaNCS} \cdot \mathrm{H}_{2} \mathrm{O}$ & 22.44 & 22.45 & 20.35 & 20.38 & 15.51 & 15.53 & - & 19.36 \\
\hline 34 & $\left(\mathrm{C}_{20} \mathrm{H}_{16} \mathrm{~N}_{8} \mathrm{~S}_{2}\right) \mathrm{LaNCS} \cdot \mathrm{H}_{2} \mathrm{O}$ & 21.33 & 21.35 & 19.35 & 19.36 & 14.74 & 14.75 & - & 22.34 \\
\hline 35 & $\left(\mathrm{C}_{22} \mathrm{H}_{20} \mathrm{~N}_{8} \mathrm{~S}_{2}\right) \mathrm{LaNCS} \cdot \mathrm{H}_{2} \mathrm{O}$ & 20.58 & 20.59 & 18.66 & 18.68 & 14.22 & 14.24 & - & 25.35 \\
\hline 36 & $\left(\mathrm{C}_{24} \mathrm{H}_{24} \mathrm{~N}_{8} \mathrm{~S}_{2}\right) \mathrm{LaNCS} \cdot \mathrm{H}_{2} \mathrm{O}$ & 19.76 & 19.75 & 17.92 & 17.90 & 13.65 & 13.64 & - & 13.19 \\
\hline
\end{tabular}

\section{RESULTS AND DISCUSSION}

The Lanthanum(III) complexes are colored, stable and non-hygroscopic in nature. The elemental analyses shows that, all the Lanthanum(III) complexes have 1:1 stoichiometry of the type $\mathrm{La}(\mathrm{III}) \mathrm{LNO}_{3} \cdot \mathrm{H}_{2} \mathrm{O}, \mathrm{La}(\mathrm{III}) \mathrm{LCl} \cdot \mathrm{H}_{2} \mathrm{O}$ and $\mathrm{La}(\mathrm{III}) \mathrm{NCS} \cdot \mathrm{H}_{2} \mathrm{O}$ respectively. The molar 
conductance values are too low to account for any dissociation of the complexes in DMF, indicating the non-electrolytic nature of the complexes (Table 1).

In order to establish whether water molecule present in the complexes coordinated to the metal ion, weighed complexes (1) and (2) were dried over $\mathrm{P}_{2} \mathrm{O}_{5}$ in a vacuum for $c a 1 \mathrm{~h}$ and then weighed again. No loss in weight was observed.

This was confirmed by heating the complexes for $c a .2 \mathrm{~h}$ at $105^{\circ} \mathrm{C}$ and no weight loss was observed. These observations suggest the water molecule in the complexes is coordinated to the metal ion.

\section{1. Infrared Spectra}

The important diagnostic bands in the IR spectra were assigned and the bands positions are given in Table 2 .

Table 2. Important Infrared Frequencies (in $\mathrm{cm}^{-1}$ ) of lanthanum(III) complexes of 3-substituted-4amino-5-mercapto-1,2,4-triazole Schiff bases along with their assignments.

\begin{tabular}{|c|c|c|c|c|c|c|c|c|c|}
\hline $\begin{array}{c}\text { Com } \\
\text { plex } \\
\text { No }\end{array}$ & $v(\mathrm{OH})$ & $\mathrm{N}(\mathrm{CN})$ & $\begin{array}{c}\text { Thiamide } \\
\text { I }\end{array}$ & $\begin{array}{c}\text { Thiamide } \\
\text { II }\end{array}$ & $\begin{array}{c}\text { Thiamide } \\
\text { III }\end{array}$ & $\begin{array}{c}\text { Thiamide } \\
\text { IV }\end{array}$ & $\mathrm{N}(\mathrm{M}-\mathrm{N})$ & $\mathrm{N}(\mathrm{M}-\mathrm{S})$ & vM-Cl) \\
\hline 1 & $3400 \mathrm{br}$ & $1625 \mathrm{~s}$ & $\begin{array}{l}1580 \mathrm{~s} \\
1555 \mathrm{~s}\end{array}$ & $1320 \mathrm{~m}$ & $1040 \mathrm{~m}$ & $670 \mathrm{~m}$ & $430 \mathrm{~m}$ & $230 \mathrm{~m}$ & - \\
\hline 2 & $3400 \mathrm{br}$ & $1620 \mathrm{~s}$ & $\begin{array}{c}1590 \mathrm{~s} \\
1530 \mathrm{~m}\end{array}$ & $1325 \mathrm{~m}$ & $1040 \mathrm{~m}$ & $675 \mathrm{~m}$ & $435 \mathrm{~m}$ & $245 \mathrm{~m}$ & - \\
\hline 3 & $3400 \mathrm{br}$ & $1615 \mathrm{~s}$ & $\begin{array}{c}1599 \mathrm{~s} \\
1525 \mathrm{~m}\end{array}$ & $1320 \mathrm{~m}$ & $1050 \mathrm{~m}$ & $670 \mathrm{~m}$ & $430 \mathrm{~m}$ & $240 \mathrm{~m}$ & - \\
\hline 4 & $3400 \mathrm{br}$ & $1620 \mathrm{~s}$ & $\begin{array}{c}1580 \mathrm{~s} \\
1530 \mathrm{~m}\end{array}$ & $1325 \mathrm{~m}$ & $1959 m$ & $670 \mathrm{~m}$ & $440 \mathrm{~m}$ & $245 \mathrm{~m}$ & - \\
\hline 5 & $3400 \mathrm{br}$ & $1620 \mathrm{~s}$ & $\begin{array}{l}1585 \mathrm{~s} \\
1530 \mathrm{~s}\end{array}$ & $1330 \mathrm{~m}$ & $1050 \mathrm{~m}$ & $675 \mathrm{~m}$ & $460 \mathrm{~m}$ & $250 \mathrm{~m}$ & - \\
\hline 6 & $\begin{array}{c}3400 \mathrm{br} \\
\mathrm{s}\end{array}$ & $1625 \mathrm{~s}$ & $\begin{array}{l}1590 \mathrm{~s} \\
1520 \mathrm{~s} \\
\end{array}$ & $1340 \mathrm{~m}$ & $1040 \mathrm{~m}$ & $670 \mathrm{~m}$ & $460 \mathrm{~m}$ & $250 \mathrm{~m}$ & - \\
\hline 7 & $3400 \mathrm{br}$ & $1620 \mathrm{~s}$ & $\begin{array}{l}1590 \mathrm{~s} \\
1525 \mathrm{~s}\end{array}$ & $1335 \mathrm{~m}$ & $1045 \mathrm{~m}$ & $675 \mathrm{~m}$ & $445 \mathrm{~m}$ & $260 \mathrm{~m}$ & - \\
\hline 8 & $3400 \mathrm{br}$ & $1625 \mathrm{~s}$ & $\begin{array}{l}1585 \mathrm{~s} \\
1535 \mathrm{~s}\end{array}$ & $1335 \mathrm{~m}$ & $1040 \mathrm{~m}$ & $670 \mathrm{~m}$ & $450 \mathrm{~m}$ & $265 \mathrm{~m}$ & - \\
\hline 9 & $3400 \mathrm{br}$ & $1620 \mathrm{~s}$ & $\begin{array}{l}1590 \mathrm{~h} \\
1555 \mathrm{~s}\end{array}$ & $1330 \mathrm{~m}$ & $1045 \mathrm{~m}$ & $665 \mathrm{~m}$ & $435 \mathrm{~m}$ & $280 \mathrm{~m}$ & - \\
\hline 10 & $3400 \mathrm{br}$ & $1615 \mathrm{~s}$ & $\begin{array}{l}1590 \mathrm{~s} \\
1550 \mathrm{~s} \\
\end{array}$ & $1330 \mathrm{~m}$ & $1045 \mathrm{~m}$ & $670 \mathrm{~m}$ & $445 \mathrm{~m}$ & $275 \mathrm{~m}$ & - \\
\hline 11 & $3400 \mathrm{br}$ & $1620 \mathrm{~s}$ & $\begin{array}{l}1585 \mathrm{~s} \\
1545 \mathrm{~s}\end{array}$ & $1335 \mathrm{~m}$ & $1040 \mathrm{~m}$ & $680 \mathrm{w}$ & $460 \mathrm{~m}$ & $270 \mathrm{~m}$ & - \\
\hline 12 & $3400 \mathrm{br}$ & $1625 \mathrm{~s}$ & $\begin{array}{l}1590 \mathrm{~s} \\
1540 \mathrm{~s}\end{array}$ & $1330 \mathrm{~m}$ & $1050 \mathrm{~m}$ & $680 \mathrm{w}$ & $455 \mathrm{~m}$ & $265 \mathrm{~m}$ & - \\
\hline 13 & $3400 \mathrm{br}$ & $1620 \mathrm{~s}$ & $\begin{array}{l}1580 \mathrm{~m} \\
1535 \mathrm{~m}\end{array}$ & $1345 \mathrm{~s}$ & $1040 \mathrm{~m}$ & $670 w$ & $430 \mathrm{~m}$ & $280 \mathrm{~m}$ & $245 \mathrm{~m}$ \\
\hline 14 & $3400 \mathrm{br}$ & $1615 \mathrm{~s}$ & $\begin{array}{l}1590 \mathrm{~m} \\
1520 \mathrm{~m}\end{array}$ & $1340 \mathrm{~s}$ & $1045 \mathrm{~m}$ & $675 w$ & $435 \mathrm{~m}$ & $235 \mathrm{~m}$ & $250 \mathrm{w}$ \\
\hline 15 & $3400 \mathrm{br}$ & $1610 \mathrm{~s}$ & $\begin{array}{l}1595 \mathrm{~m} \\
1525 \mathrm{~m}\end{array}$ & $1320 \mathrm{~s}$ & $1040 \mathrm{~m}$ & $670 \mathrm{~m}$ & $455 \mathrm{~m}$ & $240 \mathrm{~m}$ & $245 \mathrm{~m}$ \\
\hline 16 & $3400 \mathrm{br}$ & $1615 \mathrm{~s}$ & $\begin{array}{l}1585 \mathrm{~m} \\
1520 \mathrm{~m}\end{array}$ & $1325 \mathrm{~s}$ & $1050 \mathrm{~m}$ & $675 \mathrm{~m}$ & $440 \mathrm{~m}$ & $255 \mathrm{~m}$ & $240 w$ \\
\hline 17 & $3400 \mathrm{br}$ & $1620 \mathrm{~s}$ & $\begin{array}{l}1590 \mathrm{~m} \\
1540 \mathrm{~m}\end{array}$ & $1330 \mathrm{~m}$ & $1045 \mathrm{~m}$ & $670 \mathrm{~m}$ & $440 \mathrm{~m}$ & $260 \mathrm{~m}$ & $245 \mathrm{w}$ \\
\hline 18 & $3400 \mathrm{br}$ & $1610 \mathrm{~s}$ & $1580 \mathrm{~m}$ & $1340 \mathrm{~s}$ & $1050 \mathrm{~m}$ & $670 \mathrm{~m}$ & $445 \mathrm{~m}$ & $275 \mathrm{~m}$ & $250 \mathrm{~m}$ \\
\hline
\end{tabular}




\begin{tabular}{|c|c|c|c|c|c|c|c|c|c|}
\hline & & & $1540 \mathrm{~m}$ & & & & & & \\
\hline 19 & $3400 \mathrm{br}$ & $1615 \mathrm{~s}$ & $\begin{array}{l}1585 \mathrm{~m} \\
1540 \mathrm{~m}\end{array}$ & $1345 \mathrm{~s}$ & $1045 \mathrm{~m}$ & $680 \mathrm{~m}$ & $450 \mathrm{~m}$ & $270 \mathrm{~m}$ & $250 \mathrm{~m}$ \\
\hline 20 & $3400 \mathrm{br}$ & $1615 \mathrm{~s}$ & $\begin{array}{l}1590 \mathrm{~m} \\
1530 \mathrm{~m}\end{array}$ & $1340 \mathrm{~s}$ & $1050 \mathrm{~m}$ & $680 \mathrm{~m}$ & $450 \mathrm{~m}$ & $265 \mathrm{~m}$ & $255 \mathrm{~m}$ \\
\hline 21 & $3400 \mathrm{br}$ & $1615 \mathrm{~s}$ & $\begin{array}{l}1590 \mathrm{~m} \\
1530 \mathrm{~m}\end{array}$ & $1320 \mathrm{~s}$ & $1040 \mathrm{~m}$ & $670 w$ & $460 \mathrm{~m}$ & $280 \mathrm{~m}$ & $250 \mathrm{w}$ \\
\hline 22 & $3400 \mathrm{br}$ & $1610 \mathrm{~s}$ & $\begin{array}{l}1590 \mathrm{~m} \\
1530 \mathrm{~m}\end{array}$ & $1325 \mathrm{~s}$ & $1050 \mathrm{~m}$ & $680 \mathrm{~m}$ & $445 \mathrm{~m}$ & $270 \mathrm{~m}$ & $245 \mathrm{~m}$ \\
\hline 23 & $3400 \mathrm{br}$ & $1620 \mathrm{~s}$ & $\begin{array}{l}1555 \mathrm{~m} \\
1535 \mathrm{~m}\end{array}$ & $1340 \mathrm{~s}$ & $1045 \mathrm{~m}$ & $680 w$ & $435 \mathrm{~m}$ & $275 \mathrm{~m}$ & $240 \mathrm{~m}$ \\
\hline 24 & $3400 \mathrm{br}$ & $1615 \mathrm{~s}$ & $\begin{array}{l}1590 \mathrm{~m} \\
1525 \mathrm{~m}\end{array}$ & $1345 \mathrm{~s}$ & $1040 \mathrm{~m}$ & $675 w$ & $430 \mathrm{~m}$ & $260 \mathrm{~m}$ & $245 \mathrm{~m}$ \\
\hline 25 & $3400 \mathrm{br}$ & $1620 \mathrm{~s}$ & $\begin{array}{l}1580 \mathrm{~m} \\
1540 \mathrm{~m}\end{array}$ & $1345 \mathrm{~s}$ & $1040 \mathrm{~m}$ & $670 \mathrm{~m}$ & $430 \mathrm{~m}$ & $280 \mathrm{~m}$ & - \\
\hline 26 & $3400 \mathrm{br}$ & $1610 \mathrm{~s}$ & $\begin{array}{l}1590 \mathrm{~m} \\
1530 \mathrm{~m}\end{array}$ & $1330 \mathrm{~s}$ & $1040 \mathrm{~m}$ & $675 \mathrm{~m}$ & $440 \mathrm{~m}$ & $245 \mathrm{~m}$ & - \\
\hline 27 & $3400 \mathrm{br}$ & $1615 \mathrm{~s}$ & $\begin{array}{l}1580 \mathrm{~m} \\
1540 \mathrm{~m}\end{array}$ & $1340 \mathrm{~s}$ & $1050 \mathrm{~m}$ & $675 \mathrm{~m}$ & $445 \mathrm{~m}$ & $245 \mathrm{~m}$ & - \\
\hline 28 & $3400 \mathrm{br}$ & $1610 \mathrm{~s}$ & $\begin{array}{l}1590 \mathrm{~m} \\
1530 \mathrm{~m}\end{array}$ & $1345 \mathrm{~m}$ & $1050 \mathrm{~m}$ & $670 \mathrm{~m}$ & $450 \mathrm{~m}$ & $240 \mathrm{~m}$ & - \\
\hline 29 & $3400 \mathrm{br}$ & $1615 \mathrm{~s}$ & $\begin{array}{l}1590 \mathrm{~m} \\
1535 \mathrm{~m}\end{array}$ & $1340 \mathrm{~m}$ & $1045 \mathrm{~m}$ & $680 \mathrm{~m}$ & $445 \mathrm{~m}$ & $255 \mathrm{~m}$ & - \\
\hline 30 & $3400 \mathrm{br}$ & $1620 \mathrm{~s}$ & $\begin{array}{l}1585 \mathrm{~m} \\
1530 \mathrm{~m}\end{array}$ & $1345 \mathrm{~m}$ & $1040 \mathrm{~m}$ & $680 \mathrm{~m}$ & $450 \mathrm{~m}$ & $260 \mathrm{~m}$ & - \\
\hline 31 & $3400 \mathrm{br}$ & $1610 \mathrm{~s}$ & $\begin{array}{l}1580 \mathrm{~m} \\
1530 \mathrm{~m}\end{array}$ & $1340 \mathrm{~m}$ & $1040 \mathrm{~m}$ & $680 \mathrm{~m}$ & $450 \mathrm{~m}$ & $280 \mathrm{~m}$ & - \\
\hline 32 & $3400 \mathrm{br}$ & $1610 \mathrm{~s}$ & $\begin{array}{l}1580 \mathrm{~m} \\
1540 \mathrm{~m}\end{array}$ & $1340 \mathrm{~m}$ & $1040 \mathrm{~m}$ & $670 w$ & $445 \mathrm{~m}$ & $275 \mathrm{~m}$ & - \\
\hline 33 & $3400 \mathrm{br}$ & $1615 \mathrm{~s}$ & $\begin{array}{l}1590 \mathrm{~m} \\
1540 \mathrm{~m}\end{array}$ & $1340 \mathrm{~m}$ & $1050 \mathrm{~m}$ & $675 w$ & $450 \mathrm{~m}$ & $240 \mathrm{~m}$ & - \\
\hline 34 & $3400 \mathrm{br}$ & $1620 \mathrm{~s}$ & $\begin{array}{l}1585 \mathrm{~m} \\
1545 \mathrm{~m}\end{array}$ & $1335 \mathrm{~m}$ & $1045 \mathrm{~m}$ & $675 \mathrm{~m}$ & $440 \mathrm{~m}$ & $255 \mathrm{~m}$ & - \\
\hline 35 & $3400 \mathrm{br}$ & $1610 \mathrm{~s}$ & $\begin{array}{l}1590 \mathrm{~m} \\
1550 \mathrm{~m}\end{array}$ & $1340 \mathrm{~m}$ & $1040 \mathrm{~m}$ & $670 w$ & $445 \mathrm{~m}$ & $275 \mathrm{~m}$ & - \\
\hline 36 & $3400 \mathrm{br}$ & $1620 \mathrm{~s}$ & $\begin{array}{l}1585 \mathrm{~m} \\
1530 \mathrm{~m}\end{array}$ & $1345 \mathrm{~m}$ & $1045 \mathrm{~m}$ & $670 w$ & $445 \mathrm{~m}$ & $280 \mathrm{~m}$ & - \\
\hline
\end{tabular}

All the complexes do not show a broad medium band in the region $3280-3140 \mathrm{~cm}^{-1}$ nor do they show band centered around $2400 \mathrm{~cm}^{-1}$ due to $v(\mathrm{NH})$ and $v(\mathrm{SH})$ vibrations of the ligands. The characteristic band of $v(\mathrm{C}=\mathrm{S})$ around $740 \mathrm{~cm}^{-1}$ in the ligands becomes weak and shifts to lower frequency i.e around $670 \mathrm{~cm}^{-1}$. These observations favor that, the ligand reacts with metal ion in thiol form via deprotonation. This agrees with the elimination of two of three nitrate ions originally present in the metal salt. Further this confirms the involvement of sulphur donor atom in coordination to the metal ion. The bands due to thiamides-I,II,III vibrations are located in the same region as appeared in the corresponding ligands. The another characteristic band of medium to high intensity band due to $v(\mathrm{C}=\mathrm{N})$ occurring around $1635 \pm 5 \mathrm{~cm}^{-1}$ in the ligands is observed at $1625-1610 \mathrm{~cm}^{-1}$ in the complexes indicating that, 
the $\mathrm{C}=\mathrm{N}$ groups of the ligand have coordinated to the metal ion through nitrogen ${ }^{19}$. That confirms the presence of the salicylidene residue ${ }^{4}$. These observations suggest that, the ligand reacts with metal ion through all its coordinating centers.

In addition to the above band all the complexes of the type $\mathrm{LaLNO}_{3} \cdot \mathrm{H}_{2} \mathrm{O}$ exhibit some new bands appear around 1505, 1290, 1030,845, 745 and $705 \mathrm{~cm}^{-1}$ which are attributed to $v_{4}$, $v_{1}, v_{2}, v_{6}, v_{3}$ and $v_{5}$ vibrations of coordinated $\left(C_{2 v}\right)$ nitrate group respectively ${ }^{20,21}$. Since the separation between $v_{4^{-}} v_{1}$ and $v_{3^{-}} v_{5}$ are in the range of $215-210 \mathrm{~cm}^{-1}$ and $40-45 \mathrm{~cm}^{-1}$ respectively indicating that, nitrate group is coordinated in the bidentate fashion, which is ascertained by comparing the present data with recent paper $^{22,5}$.

The complexes of LaNCS $\cdot \mathrm{H}_{2} \mathrm{O}$ exhibit the N-bonded mode of coordination of thiocyante group which is confirmed by the appearance of the bands around 2105,785 and $475 \mathrm{~cm}^{-1}$, which are assigned to $v(\mathrm{C}=\mathrm{N})$ of NCS and $v(\mathrm{C}=\mathrm{S})$ of NCS and NCS bending vibrations respectively. This is further supported by an additional band due to $v(\mathrm{La}-\mathrm{N})$ vibration which has been found to appear around $285 \mathrm{~cm}^{-1}$. This is further supported by an additional band due to $v(\mathrm{La}-\mathrm{N})$ vibration which has been found to appear around $285 \mathrm{~cm}^{-1}$.

The complexes of the type $\mathrm{LaLCl} \cdot \mathrm{H}_{2} \mathrm{O}$ show the band due to $v(\mathrm{La}-\mathrm{Cl})$ at $250 \mathrm{~cm}^{-1}$ which is assigned in view of previous reports ${ }^{23}$. Metal ligand vibrations are difficult to assign on the empirical bases since their frequencies are sensitive to the metal ligand. A comparison of IR spectra between lagand and its metal complexes fail to give clear cut assignment because some ligand vibrations activated by complex formation which may appear in the same region as metal ligand vibrations. In the far IR spectra of the complexes of the several bands observed, some of them have been assigned tentatively to $v(\mathrm{M}-\mathrm{N})$ and $v(\mathrm{M}-\mathrm{S})$ vibrations $^{24,25}$. All the complexes show medium intensity bands in the region $430-460 \mathrm{~cm}^{-1}$ has been considered to be due to $v(\mathrm{M}-\mathrm{N})$ and the high intensity bands found in the 280-230 $\mathrm{cm}^{-1}$ region may be regarded due to $v(\mathrm{M}-\mathrm{S})$ vibration.

\section{2. NMR Spectra}

The NMR spectra of lanthanum(III) complexes of the ligands, the signal due to NH proton disappears suggesting that, the ligands react with the metal ion in thiol form via deprotonation. This observation supports IR inferences. The another characteristic signal due to azomethine proton in the complex of ligand I appears at $8.4 \mathrm{ppm}$ indicates a downfield shift with respect to ligand I $(8.2 \mathrm{ppm})$. This observation suggests the coordination of the azomethine moiety through the nitrogen to the metal ion. A further support for coordination of $\mathrm{C}=\mathrm{N}$ nitrogen to the downfield shift of the aromatic proton signals appear in the range of 7.2-8.3 ppm with respect to ligand No. IX (6.9-7.9 ppm). A signal due to water proton in the complexes appears at 5.4 and $5.6 \mathrm{ppm}$ respectively. The signal due to $\mathrm{CH}=\mathrm{N}$ of triazole ring of the complex $9 \mathrm{ppm}$ appeared at $8.44 \mathrm{ppm}$. All these observations provide support for the IR inferences.

\section{3. ESI-mass studies}

The ESI-mass spectra of $\left(\mathrm{C}_{6} \mathrm{H}_{4} \mathrm{~N}_{8} \mathrm{~S}_{2}\right) \mathrm{LaNO}_{3} \cdot \mathrm{H}_{2} \mathrm{O}$ complex with Schiff base I have been studied. In the spectrum of $\left(\mathrm{C}_{6} \mathrm{H}_{4} \mathrm{~N}_{8} \mathrm{~S}_{2}\right) \mathrm{LaNO}_{3} \cdot \mathrm{H}_{2} \mathrm{O}$ complex the molecular ion peak $\mathrm{M}^{+}$is observed at $\mathrm{m} / \mathrm{z} 471$ which is equivalent to its molecular weight.

\section{4. Electronic Spectra}

All these complexes show a very broad band around $450 \mathrm{~nm}$ in the visible region, which is assigned to $\mathrm{L} \rightarrow \mathrm{M}$ charge transfer transition. 


\section{5. Biological activity}

The biological activity of the newly synthesized Schiff base and its lanthanum(III) complexes has been studied for their antibacterial and antifungal activities by cup plate method $^{26}$. The microbial results are systematized in Table 3.

Table 3. Biological Results of 3-Substituted-4-amino-5-mercapto-1,2,4 triazole Schiff bases and lanthanum(III) complexes.

\begin{tabular}{|c|c|c|c|c|c|c|}
\hline \multirow{2}{*}{$\begin{array}{c}\text { Ligand } \\
\text { No }\end{array}$} & $\mathrm{R}$ & $\mathrm{R}$ & \multicolumn{4}{|c|}{$\begin{array}{c}\text { Activity Against } \\
\text { Bacteria } \\
\text { B. cirrafigellosus }\end{array}$} \\
& & & $\begin{array}{c}\text { Bacteria } \\
\text { E. coli }\end{array}$ & $\begin{array}{c}\text { Fungi } \\
\text { C. albicans }\end{array}$ & $\begin{array}{c}\text { Fungi } \\
\text { A. niger }\end{array}$ \\
\hline I & $\mathrm{H}$ & $\mathrm{H}$ & 13 & 12 & 18 & 13 \\
\hline II & $\mathrm{CH}_{3}$ & $\mathrm{H}$ & 15 & 13 & 20 & 13 \\
\hline III & $\mathrm{C}_{2} \mathrm{H}_{5}$ & $\mathrm{H}$ & 15 & 13 & 16 & 13 \\
\hline IV & $\mathrm{C}_{3} \mathrm{H}_{7}$ & $\mathrm{H}$ & 14 & 14 & 19 & 12 \\
\hline V & $\mathrm{H}$ & $\mathrm{CH}_{3}$ & 15 & 17 & 13 & 17 \\
\hline VI & $\mathrm{CH}_{3}$ & $\mathrm{CH}_{3}$ & 14 & 13 & 14 & 21 \\
\hline VII & $\mathrm{C}_{2} \mathrm{H}_{5}$ & $\mathrm{CH}_{3}$ & 16 & 14 & 16 & 19 \\
\hline VIII & $\mathrm{C}_{3} \mathrm{H}_{7}$ & $\mathrm{CH}_{3}$ & 17 & 15 & 18 & 19 \\
\hline
\end{tabular}

Metal complexes of lanthanum(III) complexes $\mathrm{LaLNO}_{3} \cdot \mathrm{H}_{2} \mathrm{O}$

\begin{tabular}{|c|c|c|c|c|c|}
\hline \multirow{2}{*}{ Ligand No } & $\begin{array}{c}\text { Complex } \\
\text { No }\end{array}$ & \multicolumn{4}{|c|}{$\begin{array}{c}\text { Activity Against } \\
\text { B. cirrafigellosus }\end{array}$} \\
& 1 & 17 & 18 & 13 & 20 \\
\hline I & 2 & 22 & 19 & 12 & 18 \\
\hline II & 3 & 18 & 11 & 10 & 20 \\
\hline III & 4 & 21 & 12 & 14 & 16 \\
\hline IV & 5 & 12 & 14 & 13 & 15 \\
\hline V & 6 & 13 & 19 & 17 & 12 \\
\hline VI & 7 & 10 & 20 & 18 & 19 \\
\hline VII & 7 & & & & \\
\hline
\end{tabular}

Metal complexes of lanthanum(III) complexes $\mathrm{LaLCl} \cdot \mathrm{H}_{2} \mathrm{O}$

\begin{tabular}{|c|c|c|c|c|c|}
\hline \multirow[b]{2}{*}{$\begin{array}{l}\text { Ligand } \\
\text { No }\end{array}$} & \multirow[b]{2}{*}{$\begin{array}{c}\text { Complex } \\
\text { No }\end{array}$} & \multicolumn{4}{|c|}{ Activity Against } \\
\hline & & $\begin{array}{c}\text { Bacteria } \\
\text { B. cirrafigellosus }\end{array}$ & $\begin{array}{l}\text { Bacteria } \\
\text { E. coli }\end{array}$ & $\begin{array}{l}\text { Fungi } \\
\text { C. albicans }\end{array}$ & $\begin{array}{l}\text { Fungi } \\
\text { A. niger }\end{array}$ \\
\hline $\mathrm{I}$ & 1 & 21 & 12 & 14 & 16 \\
\hline II & 2 & 17 & 18 & 13 & 17 \\
\hline III & 3 & 19 & 20 & 21 & 14 \\
\hline $\mathrm{V}$ & 5 & 12 & 17 & 16 & 20 \\
\hline VI & 6 & 16 & 18 & 14 & 15 \\
\hline VII & 7 & 18 & 16 & 13 & 15 \\
\hline
\end{tabular}

*Zone of inhibition in $\mathrm{mm}$ 


\begin{tabular}{|c|c|c|c|c|}
\hline DMF 0.1 ml solvent control & 11 & 11 & 11 & 11 \\
\hline Sulphomethoxozole (20 mcg) & 20 & 20 & - & - \\
\hline Gentamycin (10 mcg) & 24 & 24 & - & - \\
\hline Nystatin (50 IU) & - & - & 23 & 25 \\
\hline
\end{tabular}

Key for interpretation

Less than $13=$ Inactive, 13-16 = weakly active, $17-20=$ moderately active, $>25$ highly active.

The Schiff bases and their metal complexes were evaluated for antimicrobial activity. The results of the bactericidal study of the synthesized compounds are displayed in Table 3 , the compound VIII is moderately active whereas rest of the compounds are weakly active against B. cirrafigellosus. The compound I is inactive, the compounds II,III,IV,VI,VII and VII are weakly active and compound is moderately active against E. coli.

Amongst these compounds, III,V,VI and VII are weakly active against C. albicans whereas compounds I,II,IV and VIII exhibit moderate activity against the same organism. Amongst these, compound II exhibits high activity than the other compounds. Of all the ligands (Table 3 ) only three ( viz, I, II and III) are weakly active active against the A.niger, whereas V,VII and VIII are moderately active against the same organism. The compound VI exhibits highest activity $(21 \mathrm{~mm})$ than the remaining compounds against $\mathrm{A}$. niger.

Of the lanthanum(III) complexes of the type $\mathrm{LaLNO}_{3} \cdot \mathrm{H}_{2} \mathrm{O}, 1$ and 3 have shown moderate activity, 2 and 4 exhibit high activity, 6 has shown weak activity and the remaining complexes are inactive to B. cirrafigellosus. The complexes 1,2,6 and 7 are moderately active, 3 and 4 are inactive whereas, 5 is weakly active against E. coli. These complexes are either inactive or weakly active against C. albicans except 6 and 7, which are moderately active to the same organism. Of these 1,2,3 and 7 are moderately active whereas, 4 and 5 are weakly active to the A. niger. Complex 6 is inactive to same organism. In case of complexes of the type $\mathrm{LaLCl} \cdot \mathrm{H}_{2} \mathrm{O}, 1$ is highly active, 2,3 and 7 are moderately active, 6 is weakly active and 5 is inactive to B. cirrafigellosus, 1 is inactive and 7 is weakly active to E. coli. The remaining compounds are moderately active towards the same organism. In the study of antifungal activity only complex 3 is highly active $(21 \mathrm{~mm})$ and remaining compounds are weakly active against $\mathrm{C}$. albicans. The complexes 2 and 5 are moderately active and the remaining compounds are weakly active to A. niger.

The antibacterial and antifungal studies suggested that, all the Schiff bases were found to be biologically active and some of their metal complexes showed significantly enhanced antibacterial and antifungal activity. It is, however, known that, chelating tends to make the Schiff bases act as more powerful and potent bactereostatic agents, thus inhibiting the growth of bacteria and fungi more than the parent Schiff bases. It is suspected that, factors such as solubility, conductivity, dipole moment and cell permeability mechanism (influenced by the presence of metal ions) may be the possible reasons for the increase in activity.

\section{CONCLUSION}

The analytical data and general behavior of the complexes suggest the empirical formula of the complexes as $\mathrm{LaLNO}_{3} \cdot \mathrm{H}_{2} \mathrm{O}, \mathrm{LaLCl} \cdot \mathrm{H}_{2} \mathrm{O}$ and $\mathrm{LaLNCS} \cdot \mathrm{H}_{2} \mathrm{O}$. The molar values suggest non-electrolytic behavior of the complexes. The IR and NMR spectra suggest dibasic 
tetradentate behavior of the ligands coordinating through the azomethine nitrogen and through the sulphur atom in thiol form of the ligand. IR spectral data indicate the coordination of nitrate, chloride and thiocyanate to the metal ion.

Antibacterial and antifungal study reveals that Schiff bases and some metal complexes of lanthanum(III) complexes were found to be highly active against antibacterial and antifungal activity. All these observations taken together suggest that, a seven coordination around lanthanum(III) in the complexes of the type $\mathrm{LaLNO}_{3} \cdot \mathrm{H}_{2} \mathrm{O}$ and lanthanum(III) ion exhibits coordination number six in the complexes of the type $\mathrm{LaLCl} \cdot \mathrm{H}_{2} \mathrm{O}$ and LaLNCS $\cdot \mathrm{H}_{2} \mathrm{O}$.
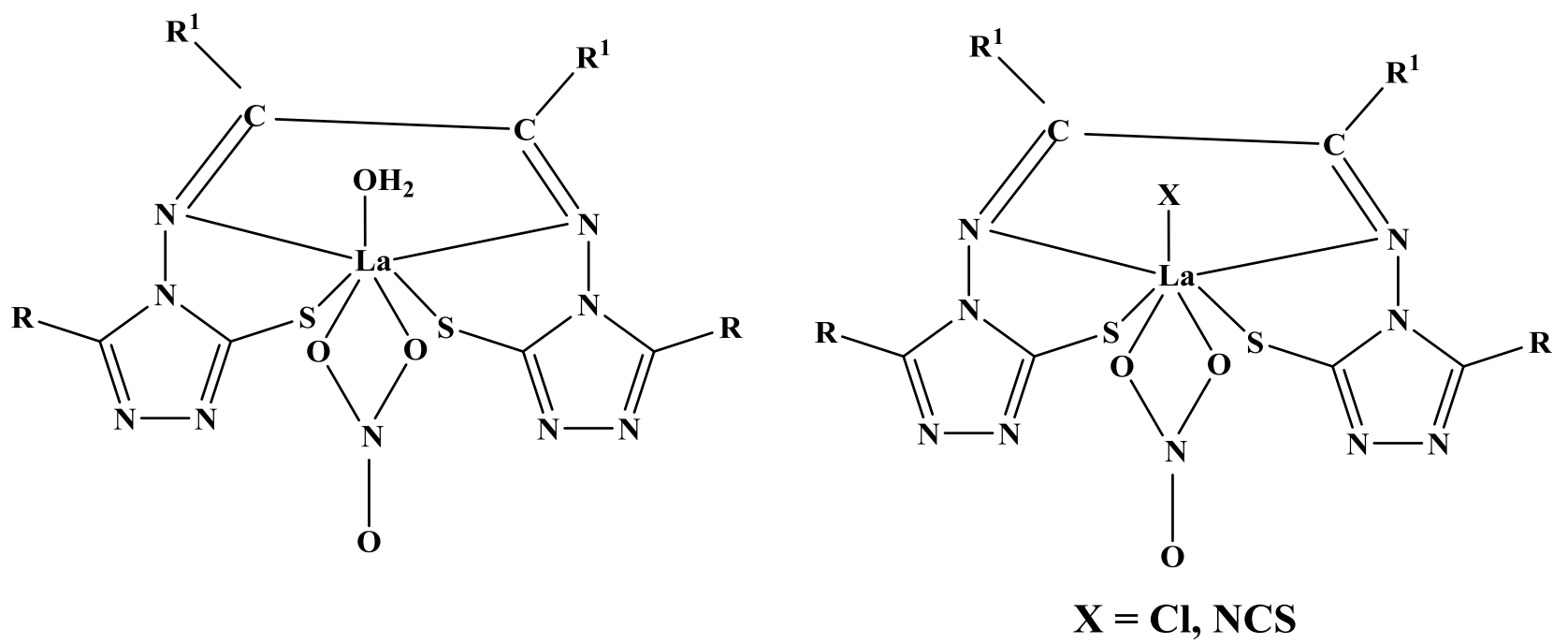

\section{Acknowledgements}

The authors are thankful to President B. L. D. E Association Bijapur, Principal, Head of chemistry S. B. Arts and K. C. P. Science College Bijapur. Special thanks to Dr. S. A. Patil Dept of Chemistry, Karnataka University Dharawad for valuable guidance.

\section{References}

[1] S. A. Patil, B. M. Badiger, S. M. Kudar,i V. H. Kulkarni., Transition Metal Chem. 8 (1983) 238 .

[2] B. M. Badiger, S. A. Patil, S. M. Kudari, V. H. Kulkarni, Rev, Roum, Chim. 31 (1986) 849.

[3] A. Y. Naik, S. D. Angadi, V. H. Kulkarni, Oriental J. Chem. 10 (1994) 23.

[4] M. S. Yadawe, S. A. Patil, Transition, Met. Chem. 22 (1997) 220.

[5] Prakash Gouda Avagi, B. Nagaraj Reddy, Sangamesh A. Patil., Transition Met. Chem. 31 (2006) 842-848.

[6] Mallikarjun S. Yadawe, Sangamesh A. Patil., Asian J. Research Chem 3(2), (2010). 
[7] S. N. Dubey, B. Kaushik, Indian J. Chem. 24A (1985) 950.

[8] J. P. Corhnelissen, J. H. Van Diemen, L. R. Groeneveld, J. G. Haasnoot, A. L. Spek, J. Reedisk., Inorg. Chem. 31 (1992) 198.

[9] A. K. Sengupta, O. P. Bajaj, U. Chandra., J. India. Chem. Soc. 55 (1978) 962.

[10] H. Singh, L. D. S. Yadav, P. K. Bhattacharya, Indian Chem. Soc. 56 (1979) 1013.

[11] G. Tanara, Jpn Kokai 973 (1974) 7495(1974), Chem. Abs. 82 (1975) 156320h.

[12] S. Giri, H. Singh, L. D. S. Yadav., J. Indian Chem. Soc. 55 (1978) 168.

[13] R. K.Shikkargol, N. N. Mallikarjun, K. Siddappa, V. H. Kulkarni, S. D. Angadi, J. Indian Chem. Soc. 78 (2001) 148.

[14] L. Misra, A. K. Yadaw, Indian J. Chem. 39A (2000) 660-663.

[15] J. C. Duff., J. Chem. Soc. 547 (1941).

[16] L. F. Audriceth, E. S. Scott, P. S. Kipper., J. Org. Chem. 19 (1954) 733.

[17] K. S. Dhaka Jagamohan, V. K. Chadha, H. K. Pujari., Indian. J. Chem. 12 (1974) 288.

[18] A. I. Vogel, Text Book of Quantitative Inorganic Analysis, $4^{\text {th edn }}$., ELBS Longmans Green and Co. Ltd. 1978.

[19] R. Shshidharan, T. R. Goudar., J. Indian Chem. Soc. 7 (2001) 8360.

[20] B. M. Gothehouse, S. E. Liingstone, R. S. Nyholm., J. Chem. Soc. (1957) 4222.

[21] N. F. Curtis, Y. M. Curtis, Inorg. Chem. 4 (1965) 804.

[22] V. V. Rana, D. P. Singh, Prabha Singh, M. P. Teotia, Indian J. Chem. 21A (1982) 528.

[23] K. Nakamoto, Infrared and Raman Spectra of Inorganic and Coordination Compounds, $4^{\text {th }}$ Edn(New York) John Wiley ( 1986) 206.

[24] J. R.Ferraro, L. J. Basile, D. L. Kovaik., Inorg. Chem. 5 (1966) 391.

[25] Prakash Gouda Avaji, Sangamesh A. Patil., Journal of Coordination Chemistry 6116 (2008) 2570-2583.

[26] J. C. Vincent, M. W. Vincent, Proc. Soc. Expt. Biol. 55 (1944) 162. 